\title{
Comparison of fibre digestion and digesta retention time between rabbits, guinea-pigs, rats and hamsters
}

\author{
BY EI SAKAGUCHI, HIROSHI ITOH, SENJI UCHIDA \\ AND TAKAO HORIGOME \\ Department of Animal Science, College of Agriculture, Okayama University, \\ Okayama 700, Japan
}

(Received 16 June 1986 - Accepted 23 February 1987)

\begin{abstract}
1. Digestive efficiencies of fibre components and retention time of digesta in the whole gut and in the large intestine were measured in rabbits, guinea-pigs, hamsters and rats when given a lucerne (Medicago sativa)containing diet.

2. Co-EDTA and chromium-mordanted cell-wall constituents of Italian ryegrass (Lolium multiflorum L.) were used as liquid- and solid-phase markers respectively. Both markers were mixed with the experimental diet and given after digestion trials.

3. Mean retention times of each marker were calculated from time-course changes in concentrations of the markers in faeces. The mean retention times of the markers in the large intestine were calculated from exponential slopes fitted to the time-course changes of faecal concentrations of the markers.

4. The digestibilities of crude fibre, neutral-detergent fibre and acid-detergent fibre were highest in the guineapigs, followed by the hamsters, and lowest in the rabbits and rats.

5. The mean retention times of $\mathrm{Cr}$ in the whole tract were longer in the larger animals and shortest in the hamsters. The mean retention times of $\mathrm{Cr}$ in the large intestine were longest in the guinea-pig followed by the hamsters and the rats. The rabbits had an extremely short retention time of $\mathrm{Cr}$ in the large intestine.

6. These results suggest that the retention time of solid digesta in the large intestine can explain the difference in the digestive efficiencies of fibre components amongst non-ruminant small herbivores whereas retention of digesta in the whole gut is not related to the digestibility of fibre components.
\end{abstract}

Rabbits, guinea-pigs and hamsters are non-ruminant animals classified as herbivores, whereas rats are omnivores widely used as experimental animals. All these animals possess a comparatively well-developed caecum. Digestion of dietary fibre is accomplished in the large intestine in non-ruminant herbivores, and these species are called hind-gut fermenters (Hume \& Warner, 1980). Caecoaectomy results in a decrease in the digestibility of dry matter and fibre in the hamster (Sakaguchi et al. 1981), the rat (Dreyer \& Mahon, 1982; Williams \& Senior, 1982) and pig (Lloyd et al. 1958). The extent of fibre digestion varies, however, amongst the non-ruminant herbivores (Slade \& Hintz, 1969; Udén \& Van Soest, 1982). This is thought to be due to differences in the ability of the large intestines of different animals to break down fibre.

Some reports (Slade \& Hintz, 1969; Clemens \& Stevens, 1980; Udén et al. 1982) have shown a negative correlation between transit time of digesta through the whole gastrointestinal tract and the digestibility of fibre in non-ruminant animals. The retention time of digesta in the large intestine, where fibre is digested by intestinal microbes, is an important factor which affects the digestibility of fibre in non-ruminant animals, because it is widely recognized that the digestibility of fibre is closely connected with rumen retention time of digesta in ruminants (Van Soest, 1982).

The objective of the present study was to examine whether the variation in the digestibility of fibre amongst non-ruminant animals was related to the retention time of digesta in the large intestine of each species. 
Table 1. Composition $(\mathrm{g} / \mathrm{kg})$ of the experimental diet

\begin{tabular}{lr}
\hline Ingredients & \\
Lucerne (Medicago sativa) meal & 500 \\
Defatted milk powder & 150 \\
Wheat bran & 150 \\
Maize oil & 50 \\
Maize & 50 \\
Sucrose & 50 \\
Mineral mix* & 30 \\
Vitamin mix $\dagger$ & 20 \\
& \\
Analysis & \\
Moisture & 85 \\
Organic matter & 833 \\
Crude protein (nitrogen $\times 6 \cdot 25)$ & 196 \\
Diethyl ether extracts & 76 \\
Crude fibre & 126 \\
NDF & 250 \\
ADF & 176 \\
Crude ash & 82 \\
\hline
\end{tabular}

NDF, neutral detergent fibre (Van Soest \& Wine, 1967); ADF, acid detergent fibre (Van Soest, 1963).

* Composition (g/kg mixture): $145 \cdot 6 \mathrm{CaHPO}_{4} .2 \mathrm{H}_{2} \mathrm{O}, 257 \cdot 2 \mathrm{KH}_{2} \mathrm{PO}_{4}, 93 \cdot 5 \mathrm{NaH}_{2} \mathrm{PO}_{4} . \mathrm{H}_{2} \mathrm{O}, 46 \cdot 6 \mathrm{NaCl}, 350 \cdot 9$ Ca-lactate, $31.4 \mathrm{Fe}$-citrate, $71 \cdot 7 \mathrm{MgSO}_{4}, 1 \cdot 1 \mathrm{ZnCO}_{3}, 1 \cdot 2 \mathrm{MnSO}_{4} .6 \mathrm{H}_{2} \mathrm{O}, 0.3 \mathrm{CuSO}_{4} .5 \mathrm{H}_{2} \mathrm{O}, 0.1 \mathrm{KI}$.

† Composition (mg/kg mixture): 172 retinol acetate, 2.5 cholecalciferol, 1200 thiamin hydrochloride, 4000 riboflavin, 800 pyridoxine hydrochloride, 0.5 cyanocobalamin, 30000 ascorbic acid, $5000 \mathrm{DL}$ - $\alpha$-tocopheryl acetate, 5200 menadione, 20 biotin, 200 pteroylmonoglutamic acid, 5000 calcium pantothenate, 5000 -aminobenzoic acid, 6000 nicotinic acid, $6000 \psi$-inositol, 200000 choline chloride.

\section{MATERIALS AND METHODS}

Animals and feeding

Eight male rabbits (mean weight $1757 \mathrm{~g}$ ), five male guinea-pigs (mean weight $377 \mathrm{~g}$ ), six male golden hamsters (mean weight $105 \mathrm{~g}$ ) and six male rats (mean weight $295 \mathrm{~g}$ ) were used for the experiments. The hamsters and the rats were housed individually in $150 \times 200 \mathrm{~mm}$ wire-bottomed metabolism cages for $9 \mathrm{~d}$. The rabbits and the guinea-pigs were housed individually in round, wire-bottomed $(0.5 \mathrm{~m}$ diameter) metabolism cages for 10 and $8 \mathrm{~d}$ respectively. The animal room was maintained at a temperature of $22 \pm 2^{\circ}$. A $14 \mathrm{~h}$ light$10 \mathrm{~h}$ dark cycle was maintained automatically.

Feed consumption of each animal was recorded daily. Faeces and urine were collected daily during the last $4 \mathrm{~d}$ for the guinea-pigs, and the last $5 \mathrm{~d}$ for the rabbits, hamsters and rats in the digestion trials.

Markers of liquid and solid digesta were mixed with a small amount of the experimental diet and given $2-5 \mathrm{~h}$ after the digestion trials. The guinea-pigs, hamsters and rats were starved for $2 \mathrm{~h}$, and the rabbits for $5 \mathrm{~h}$ before they were given the markers, so that the experiment began under similar conditions for all the animals. Faecal samples were taken every $2 \mathrm{~h}$ for the first $48 \mathrm{~h}$ and every $4 \mathrm{~h}$ for the further $24 \mathrm{~h}$ after dosing.

During the experiments all animals were given an experimental cubed diet containing lucerne (Medicago sativa) meal ad lib. The composition of the experimental diet is shown in Table 1. Water was available freely. Coprophagy was not prevented so that feeding habits were as normal as possible. 
Table 2. Body-weight, weight gain and feed intake in the rabbits, guinea-pigs, rats and hamsters

(Mean values and standard deviations for body-weights; mean values with their standard errors for feed intake; no. of animals in parentheses)

\begin{tabular}{|c|c|c|c|c|c|c|c|c|c|}
\hline & \multicolumn{2}{|c|}{$\begin{array}{c}\text { Rabbit } \\
(n 8)\end{array}$} & \multicolumn{2}{|c|}{$\begin{array}{l}\text { Guinea-pig } \\
(n 5)\end{array}$} & \multicolumn{2}{|c|}{$\begin{array}{c}\text { Rat } \\
(n 6)\end{array}$} & \multicolumn{2}{|c|}{$\begin{array}{l}\text { Hamster } \\
\quad(n 6)\end{array}$} & \multirow[b]{2}{*}{ SEM } \\
\hline & Mean & SD & Mean & SD & Mean & SD & Mean & SD & \\
\hline $\begin{array}{l}\text { Body-wt at the beginning } \\
\text { of the trials }(\mathrm{g})\end{array}$ & 1757 & 392 & 377 & 6 & 295 & 11 & 105 & 7 & \\
\hline Daily wt gain $(\mathrm{g})$ & $0 \cdot 6$ & $11 \cdot 5$ & 6.9 & $1 \cdot 1$ & $1 \cdot 4$ & $0 \cdot 3$ & $3 \cdot 7$ & 0.4 & \\
\hline \multicolumn{10}{|l|}{ Daily intake of feed: } \\
\hline $\mathrm{g} / \mathrm{kg}$ body-wt & $55 \cdot 6^{A}$ & & $82 \cdot 0^{\mathrm{B}}$ & & $80 \cdot 4^{B}$ & & $95 \cdot 8^{C}$ & & $3 \cdot 4$ \\
\hline $\mathrm{g} / \mathrm{kg}$ body-wt ${ }^{0 \cdot 75}$ & $60 \cdot 9$ & & $64 \cdot 9$ & & $59 \cdot 6$ & & $55 \cdot 0$ & & $3 \cdot 4$ \\
\hline
\end{tabular}

A, B,C Mean values in the same horizontal row with different superscript letters are significantly different $(P<0-01)$.

\section{Markers}

Cr-mordanted Italian ryegrass (Lolium multiflorum L.) cell-wall constituents (Cr-CWC) as a particulate marker and Co-EDTA as a liquid-digesta marker were used to estimate retention time. $\mathrm{Cr}-\mathrm{CWC}$ was ground to coarse particle size and passed through a 40 mesh screen. The resulting particles were then passed through a 20 mesh screen and those which remained on the screen were used in the experiment. The diameter of the particles was in the range $0 \cdot 381-0.840 \mathrm{~mm}$ and the length was shorter than $5 \mathrm{~mm}$.

\section{Analytical methods}

The pooled faecal samples from the digestion trials were oven-dried at $60^{\circ}$, ground and analysed in duplicate for nitrogen, crude fibre, diethyl ether extracts and crude ash (Association of Official Analytical Chemists, 1975), for neutral-detergent fibre (NDF) and acid-detergent fibre (ADF) by the methods described by Van Soest \& Wine (1967) and Van Soest (1963) respectively, and for gross energy by bomb calorimetry.

To determine concentrations of $\mathrm{Cr}$ and $\mathrm{Co}$, faecal samples were dried and ashed at $550^{\circ}$ for $5 \mathrm{~h}$. The ashed samples were treated according to the method described by Williams et al. (1962). Analysis of $\mathrm{Cr}$ and $\mathrm{Co}$ in the treated sample was made by atomic absorption spectroscopy (atomic absorption spectrophotometer AA-80; Nippon Jarrell-Ash, Kyoto).

\section{Calculations}

Single exponential regression equations were fitted statistically to the time-course decline of the faecal concentrations of $\mathrm{Cr}$ in all animals and $\mathrm{Co}$ in guinea-pigs and rats. A turnover time of each marker was estimated from the decline in the faecal marker concentration according to the function (Brandt \& Thacker, 1958):

$$
Y=Y_{0} \times \mathrm{e}^{-k t},
$$

where $Y$ is the concentration of $\mathrm{Cr}$ or Co in faeces at time $t, Y_{\mathrm{o}}$ is the constant depending on the level of $\mathrm{Cr}$ or $\mathrm{Co}$ fed, $k$ is the rate-constant and $t$ is the time interval after feeding of the markers $(h)$.

Turnover time was calculated as the reciprocal of the rate-constant $(k)$ of the exponential curve fitted to the time-course excretion values of the markers after faecal marker con- 
Table 3. Apparent digestibilities $(\mathrm{g} / \mathrm{g}$ ) of feed in the rabbits, guinea-pigs, rats and hamsters

(Mean values with their standard errors; no. of animals in parentheses)

\begin{tabular}{|c|c|c|c|c|c|}
\hline & Rabbit ( $n 8)$ & Guinea-pig (n 5) & Rat $(n 6)$ & Hamster ( $n$ 6) & SEM \\
\hline Dry matter & $0.601^{\mathrm{a}}$ & $0.709^{\mathrm{h}}$ & $0 \cdot 599^{\mathrm{a}}$ & $0.665^{\mathrm{c}}$ & $0 \cdot 012$ \\
\hline Organic matter & $0.605^{a}$ & $0.705^{\mathrm{b}}$ & $0 \cdot 609^{a}$ & $0.662^{\mathrm{c}}$ & 0.012 \\
\hline Crude protein (nitrogen $\times 6.25$ ) & $0 \cdot 656^{\mathrm{a}}$ & $0.761^{\mathrm{b}}$ & $0 \cdot 703^{\mathrm{a}}$ & $0.707^{\mathrm{a}}$ & 0.017 \\
\hline Diethyl ether extracts & $0.773^{\mathrm{a}}$ & $0 \cdot 761^{\mathrm{a}}$ & $0.855^{\mathrm{b}}$ & $0.825^{\mathrm{ab}}$ & $0 \cdot 023$ \\
\hline Crude fibre & $0 \cdot 104^{A}$ & $0 \cdot 336^{\mathrm{B}}$ & $0 \cdot 137^{\mathrm{A}}$ & $0.238^{\mathrm{C}}$ & 0.024 \\
\hline NDF & $0 \cdot 208^{a c}$ & $0.391^{\mathrm{b}}$ & $0 \cdot 174^{a}$ & $0.265^{\mathrm{c}}$ & 0.024 \\
\hline $\mathrm{ADF}$ & $0 \cdot 180^{\mathrm{A}}$ & $0 \cdot 387^{\mathrm{B}}$ & $0 \cdot 155^{\mathrm{A}}$ & $0.265^{\mathrm{C}}$ & 0.020 \\
\hline
\end{tabular}

NDF, neutral detergent fibre (Van Soest \& Wine, 1967); ADF, acid detergent fibre (Van Soest, 1963).

$\mathbf{x , b , c}$ Mean values in the same horizontal row with different superscript letters are significantly different $(P<0.05)$.

${ }_{A} B_{r} C$ Mean values in the same horizontal row with different superscript letters are significantly different $(P<0.01)$.

centration reached a maximum. Total mean retention time (MRT) in the gastrointestinal tract was calculated as the sum of the reciprocal of $k$ and transit time (TT) equal to the first appearance of the marker after a dose.

\section{Statistics}

The significance of the regression line fitted to the decline of faecal marker was tested by Student's $t$ test (Snedecor \& Cochran, 1967). All results were tested for statistical difference by analysis of variance (Snedecor \& Cochran, 1967) and Duncan's multiple-range test (Duncan, 1955).

\section{RESULTS}

\section{Body-weight and feed consumption}

Body-weight, daily weight gain and daily feed intake in the rabbits, guinea-pigs, rats and hamsters during the digestion trials are shown in Table 2. The rabbits almost maintained their weights, but the guinea-pigs, hamsters and rats gained in weight during the digestion trials. The hamsters had the largest feed intake per $\mathrm{kg}$ body-weight, followed by the guineapigs, rats and rabbits. However, daily feed intake on a metabolic body size (per kg bodyweight ${ }^{0.75}$ ) basis was about $60 \mathrm{~g}$ for the four species, although values for the guinea-pigs were significantly higher than those for the hamsters.

\section{Apparent digestibility}

Apparent digestibilities of dry matter, crude protein, crude fibre, NDF, ADF and diethyl ether extracts are shown in Table 3. The guinea-pigs had the highest coefficients of digestibility for the dietary components amongst the four animal species. Digestibility of fibre and its components was highest in the guinea-pigs followed by the hamsters, and lowest in the rabbits and the rats. There was not much difference in the digestibilities of $\mathrm{N}$ and diethyl ether extracts amongst the four species. The rabbits and rats had similar digestibilities for all components.

\section{Excretion curves of markers}

Fig. 1 shows faecal marker excretion curves for one animal from each of the four groups studied. The faecal marker concentrations were plotted as the mid-point during the 

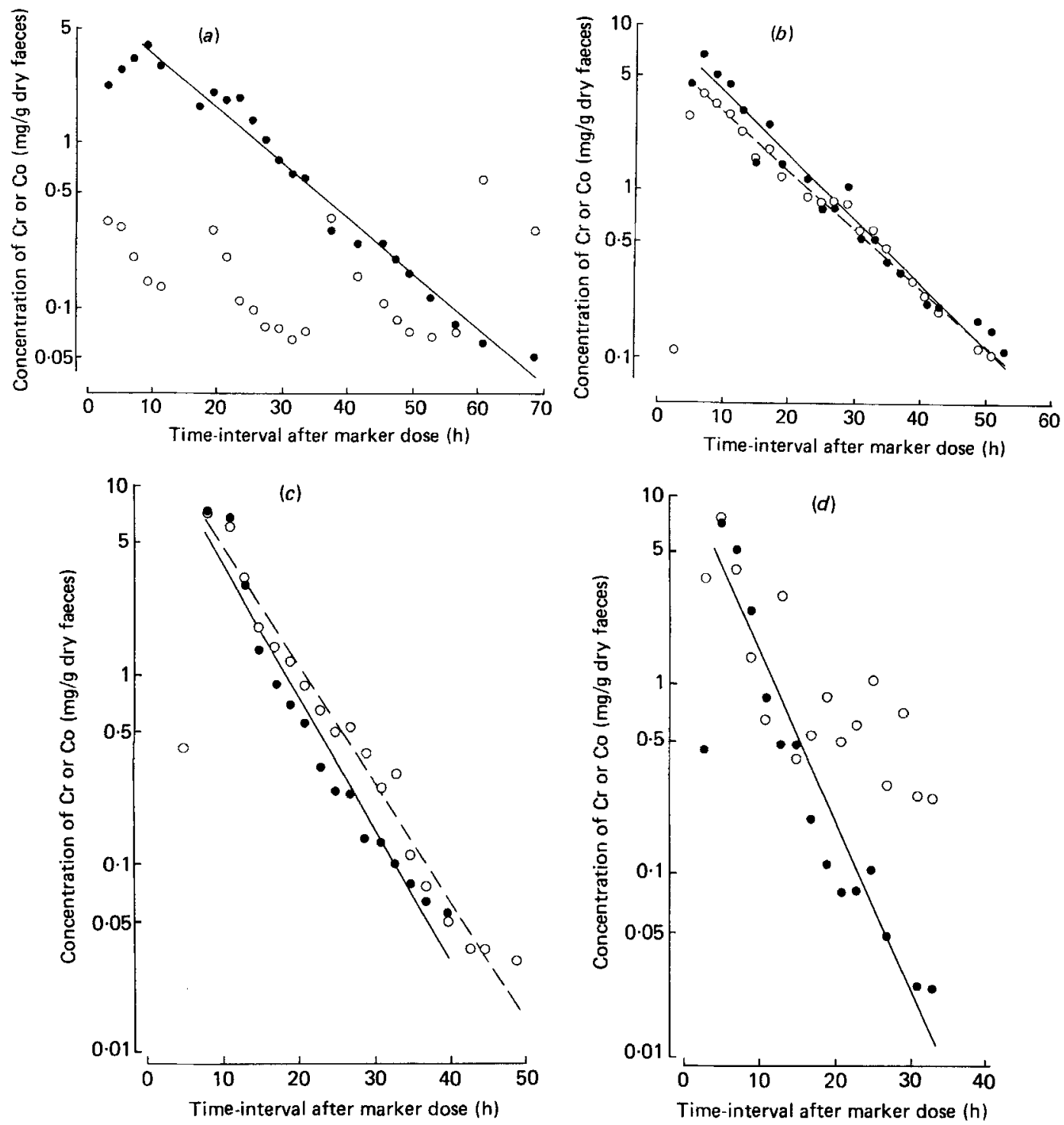

Fig. 1. Faecal marker concentrations in dry faeces following an oral dose in one example for each of the animal species studied: (a) rabbits, (b) guinea-pigs, (c) rats, $(d)$ hamsters. Chromium-mordanted cell walls $(O)$ and Co-EDTA $(O)$ were given at a single feeding with the diet. The regression lines of the timecourse reductions in $\mathrm{Cr}(\longrightarrow)$ and $\mathrm{Co}(---)$ are expressed as

$$
Y=Y_{0} \times \mathrm{e}^{-k t} \text {, }
$$

where $Y$ is the concentration of $\mathrm{Cr}$ or $\mathrm{Co}$ at time $t, Y_{\mathrm{o}}$ is the constant depending on the level of $\mathrm{Cr}$ or Co feed, $k$ is the rate-constant and $t$ is the time interval after feeding of the markers (h). The values of $Y_{o}$ and $k$ for $\mathrm{Cr}$ are $7.542,0.0772$ for the rabbit; $9.451,0.0875$ for the guinea-pig; $18.441,0.1593$ for the rat; and $10.848,0.2043$ for the hamster. The values of $Y_{0}$ and $k$ for $C_{0}$ are $6.633,0.0811$ for the guineapig and $18.259,0.1417$ for the rat. The regression equation in the rabbit and hamster was not calculated for $\mathrm{Co}$ because of the irregular variation of the plots. 
Table 4. Transit time $(T T, h)$ and mean retention time $(M R T, h)$ of liquid particle digesta markers in rabbits, guinea-pigs, rats and hamsters

(Mean values with their standard errors; no. of animals in parentheses)

\begin{tabular}{|c|c|c|c|c|c|}
\hline Marker & Rabbit ( $n$ 7) & Guinea-pig ( $n$ 5) & Rat $(n 6)$ & Hamster ( $n$ 6) & SEM \\
\hline \multicolumn{6}{|l|}{ Particle* } \\
\hline $1 / k_{\ddagger}^{\ddagger}$ & $11 \cdot 9^{\mathrm{A}}$ & $11 \cdot 7^{\mathrm{A}}$ & $5.9^{\mathrm{B}}$ & $5 \cdot 7^{\mathrm{B}}$ & 0.9 \\
\hline TT\& & $3 \cdot 8^{\mathrm{A}}$ & $4 \cdot 2^{\mathrm{A}}$ & $7 \cdot 2^{\mathrm{B}}$ & $3 \cdot 3^{\mathrm{A}}$ & 0.5 \\
\hline MRT\| & $15 \cdot 7^{\mathrm{a}}$ & $15 \cdot 9^{\mathrm{a}}$ & $13 \cdot 1^{\mathrm{ab}}$ & $9 \cdot 1^{\mathrm{b}}$ & 1.9 \\
\hline \multicolumn{6}{|l|}{ Liquid $\dagger^{\prime \prime}$} \\
\hline $1 / k_{\ddagger}^{\ddagger}$ & nd & $13 \cdot 3^{\mathrm{a}}$ & $6 \cdot 1^{b}$ & nd & $2 \cdot 0$ \\
\hline TT§ & nd & $3 \cdot 0^{\mathrm{a}}$ & $6 \cdot 0^{\mathrm{b}}$ & nd & 1.6 \\
\hline MRT $\|$ & nd & $16 \cdot 3$ & $12 \cdot 1$ & nd & 3.0 \\
\hline
\end{tabular}

nd, Not determined.

$A, B$ Mean values in the same horizontal row with different superscript letters are significantly different $(P<0 \cdot 01)$.

$\mathbf{a}, \mathbf{b}, \mathbf{c}$ Mean values in the same horizontal row with different superscript letters are significantly different $(P<0.05)$.

* Cr mordanted cell-wall constituents (Uden et al. 1980).

+ Co-EDTA.

\# Rate-constant which is considered as a dilution rate $(/ \mathrm{h})$ of the marker in the pool of the digestive tract.

$\S$ Time-interval between feeding and first appearance of the marker in the faeces.

$\|$ Sum of $1 / \mathrm{k}$ and TT.

sequence of collections. The $\mathrm{Cr}$ excretion curves were generally smooth in all four species. The excretion curves of Co were smooth only in the guinea-pig and rat. Considerable irregularity was noticed in the excretion pattern of $\mathrm{Co}$ in the rabbit and hamster. No equation could be fitted to the time-course changes for the excretion of $\mathrm{Co}$, particularly in the rabbit. Excretion curves of markers could be obtained for seven rabbits only, since one had diarrhoea after administration of the markers. Definite periodicity was observed in the excretion of $\mathrm{Co}$ by the rabbit reported in Fig. 1. Such periodical excretion of Co was also observed in three of the other rabbits examined but not in the remainder. There was a large variation between rabbits in the excretion of $\mathrm{Co}$.

The faecal concentrations of $\mathrm{Cr}$ in all animals and those of $\mathrm{Co}$ in the guinea-pig and the rat rose rapidly to a maximum after the first appearance of the markers after the dose, and accordingly a single volume model was applied to the excretion of the markers (Brandt \& Thacker, 1958).

\section{Mean retention time (MRT) of $\mathrm{Cr}$ and $\mathrm{Co}$}

TT and MRT of the markers are shown in Table 4. MRT of $\mathrm{Cr}(1 / k+\mathrm{TT})$ was highest in the rabbits, followed by the guinea-pigs, the rats and the hamsters. For the guinea-pigs and rats, the MRT of Co was also calculated. There was no difference in MRT between Cr and Co in these two species. Since the excretion pattern of Co was not smooth in the rabbits and hamsters, MRT of Co could not be calculated by compartmental analysis.

Fig. 2 shows mean plots of the digestibility of ADF, and the MRT for $\mathrm{Cr}$ which is thought to travel with solid matter in the digestive tract. No relation between the digestibility of ADF and the MRT of $\mathrm{Cr}$ was detected amongst the animal species.

The relation between the TT of $\mathrm{Cr}$ in the large intestine and the digestibilities of fibrous compounds (ADF) is shown in Fig. 3. Since $k$ for the rabbits could be regarded as the rateconstant in the stomach, whereas $k$ for the guinea-pigs, hamsters and rats, is considered as the rate-constant of the dilution of particulate digesta in the large intestine, the mean TTs (h) estimated for $\mathrm{Cr}$ in the large intestine were 0 for the rabbits, 11.7 for the guinea-pigs, 


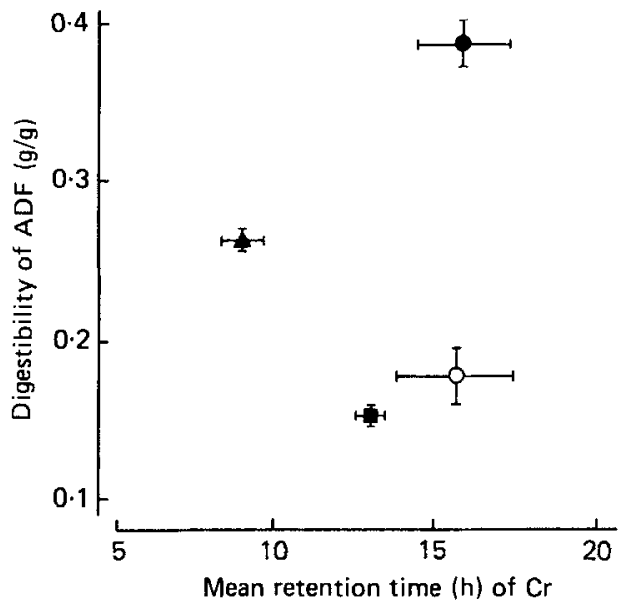

Fig. 2. Digestibilities of acid-detergent fibre (ADF) and mean retention time of $\mathrm{Cr}$ in the gastrointestinal tract in rabbits $(n 8,0)$, guinea-pigs $(n 5,0)$, rats $(n 6, \square)$ and hamsters $(n 6, \Delta)$. Points are mean values with their standard errors represented by bars. The values were obtained from Tables 3 and 4 .

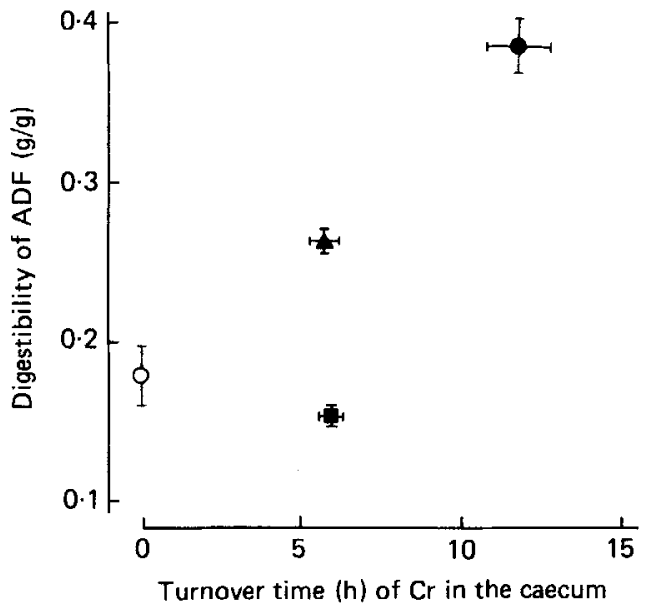

Fig. 3. Digestibilities of acid-detergent fibre (ADF) and turnover time of chromium in the caecum in rabbits $(n 7,0)$, guinea-pigs $(n 5,0)$, rats $(n 6, \square)$ and hamsters $(n 6, \Delta)$. Points are mean values with their standard errors represented by bars. The values were obtained from Tables 3 and 4 .

5.9 for the rats and 5.7 for the hamsters. The mean plots in the guinea-pigs, hamsters and rabbits gave a straight line, which shows a high correlation between the digesta retention in the intestine and the digestion of fibre, although the mean plot of the rats deviates from the TT-digestibility line of the other three species.

\section{DISCUSSION}

The guinea-pig is a strictly herbivorous, non-ruminant animal with a voluminous caecum which can retain digesta for a considerable time (Sakaguchi et al. 1986). The guinea-pig was the most efficient in the digestion of the fibre and its components among the species tested in the present study. It has been reported that guinea-pigs digest organic matter and crude fibre as efficiently as horses and ponies (Slade \& Hintz, 1969). 
Rabbits are recognized to be less efficient than guinea-pigs in the digestion of crude fibre (Slade \& Hintz, 1969) but as efficient as rats in the digestion of cellulose and hemicellulose (Fonnesbeck et al. 1974). Similar findings were obtained in the present experiment.

Rabbits possess a large caecum and their habit of coprophagy (Hörnicke \& Björnhag, 1980 ) increases the efficiency of digestion of dry matter (Thacker \& Brandt, 1955; Gioffre et al. 1980). However, little change in the digestibility of fibre components was detected when rabbits wore neck collars to prevent coprophagy (Udén \& Van Soest, 1982), suggesting that the importance of coprophagy in the utilization of fibrous matter in the animal is questionable.

The golden hamster and the rat also have a well-developed caecum. Removal of the caecum decreased the digestibility of dry matter for hamsters fed on a high-fibre diet (Sakaguchi et al. 1981). Furthermore, removal of the caecum results in a marked decrease in the digestibility of fibre in the rat (Williams \& Senior, 1982). However the digestibility of fibre is not affected by removal of the caecum in the rabbit (Gioffre et al. 1980). These findings suggest that the caecum has a significant role in the digestion of fibre in the hamster and rat, but not in the rabbit.

In the guinea-pig, digesta are retained longest in the caecum and upper proximal colon (Sakaguchi et al. 1985). When markers are injected into the caecum, the rate-constant of marker dilution in caecal contents agrees with that in the faeces. Furthermore, the rateconstant of marker dilution in the faeces after oral application agrees closely with that in caecal contents and that in the faeces after caecal injection (Sakaguchi et al. 1986). These findings suggest that the dilution rate of marker in the faeces can be regarded as a reflection of marker dilution in the caecum after oral application. The retention time of digesta in the large intestine (mainly caecum) can, therefore, be calculated from the faecal values for marker excretion in the guinea-pig.

As single exponential regressions were well fitted to the excretion of $\mathrm{Cr}$, the hamster and rat, like the guinea-pig, can be regarded as having only one main site which retains digesta, the caecum, confirming Varga's (1976) findings for the rat. The hamster has a distinctly compartmentalized stomach consisting of a glandular stomach as well as a forestomach which is not critical to nutrient digestibility in hamsters (Ehle \& Warner, 1978) or rats (Kunstýr et al. 1976), the retention time of digesta being extremely short in the hamster (Murai et al. 1982). Digesta are retained in the caecum by antiperistaltic propulsive waves in the colon of rats and guinea-pigs (Hukuhara \& Neya, 1968). The rate-constant of the excretion curve of markers in the faeces is, therefore, regarded as the rate-constant of the dilution in the caecum in hamsters and rats.

The faecal marker-excretion curves suggest that for the rabbit also there is only one compartment which retains particulate digesta. Pickard \& Stevens (1972) showed that solid markers injected into the stomach were retained for a long time in the stomach, while liquid markers left the stomach faster. There was no evidence for the accumulation of the solid markers in the caecum of the rabbit. Björnhag (1972) described the selective retention of fine particles $(<0.1 \mathrm{~mm})$ and liquid in the rabbit caecum. These findings suggest that particulate digesta are retained longer in the stomach but pass rapidly through the large intestine. Particles larger than $0.381 \mathrm{~mm}$ diameter were used as the solid marker in the present experiment, thus the rate-constant $(k)$ of the excretion curve of $\mathrm{Cr}$ can be regarded as a reflection of the dilution of the markers in the stomach in the rabbit. It is considered, therefore, that the particulate marker only passed through the large intestine in the present experiment.

The difference in the digestibility of fibre and the TT of solid digesta in the large intestine are closely related in the non-ruminant herbivores used in the present experiment (Fig. 3). An exact linear relation was observed in the mean plots for rabbits, guinea-pigs and 
hamsters $\left(r^{2} 099, n 3\right)$. As the mean plot for rats in Fig. 3 is derived from the straight regression line of the mean plots of the MRT of $\mathrm{Cr}$ and digestibility of ADF for guineapigs, hamsters and rabbits, the differences in the digestibilities of fibre amongst the animal species cannot be explained only by the differences in the retention time of digesta in the large intestine. It is very interesting that rabbits, guinea-pigs and hamsters are classified as herbivores but rats are classified as omnivores (Van Soest, 1982). MRT in the whole tract was not related to the differences in the digestibility of fibre amongst the animal species (Fig. 2). Therefore, the TT of digesta in the whole gut cannot always explain the differences in the digestibility of fibre amongst different animal species.

The irregularity and delay in the excretion of $\mathrm{Co}$ when compared with $\mathrm{Cr}$ could be attributed to selective retention of liquid in the caecum and possible recycling by caecotrophy in rabbits. Definite periodicity observed in the excretion of Co in several animals suggests that movement of liquid phase digesta in the gastrointestinal tract is intermittent in the rabbit. Although the cycle of Co excretion did not always show circadian rhythm as reported for the rabbit by Hörnicke et al. (1984), it could be considered that there is a possible association between the excretion of Co and that of soft faeces. However, further detailed experiments are needed in order to clarify the relation between the caecotrophy and marker excretion, because coprophagy was not prevented in the present experiment. Considerable individual variation in the function of the large intestine should be considered because of large variation between the Co excretion of the individual rabbits observed in the experiment.

The irregularity and delay of Co excretion in the hamster were not as marked as in the rabbit but were clearly distinguishable from the excretion of $\mathrm{Cr}$. So it can be presumed that the digestive tract of the hamster can selectively retain fluid.

Coprophagy is commonly observed in many rodents. As coprophagy was not prevented in the present experiment, it is possible that a certain proportion of the marker was recirculated in the gastrointestinal tract. If considerable amounts of $\mathrm{Cr}$ were recirculated by coprophagy, the time-course change of faecal concentration of $\mathrm{Cr}$ should become more irregular like that of $\mathrm{Co}$ in the rabbit. However, the decrease in faecal concentration of $\mathrm{Cr}$ was linear for all animals in the present experiment, which would suggest that negligible amounts of $\mathrm{Cr}$ were recirculated by coprophagy.

\section{REFERENCES}

Association of Official Analytical Chemists (1975). Official Methods of Analysis of the Association of Analytical Chemists. 12th ed. Washington, DC: Association of Official Analytical Chemists.

Björnhag, G. (1972). Swedish Journal of Agricultural Research 2, 125-136.

Brandt, C. S. \& Thacker, E. J. (1958). Journal of Animal Science 17, 218-223.

Clemens, E. T. \& Stevens, C. E. (1980). Journal of Agricultural Science, Cambridge 94, 735-737.

Dreyer, J. J. \& Mahon, E. H. (1982). South African Journal of Science 78, 73-75.

Duncan, D. B. (1955). Biometrics 11, $1-42$.

Ehle, F. R. \& Warner, R. G. (1978). Journal of Nutrition 108, 1047-1053.

Fonnesbeck, P. V., Harris, L. E. \& Kearl, L. C. (1974). Journal of Animal Science 39, 182.

Gioffre, F., Gisberti, C., Angelini, A. \& Proto, V. (1980). Annali della Facolta di Scienze Agrarie dell Universita di Napoli in Portici Serie IV, 14, pp. 84 92.

Hörnicke, H. \& Björnhag, G. (1980). In Digestive Physiology and Metabolism in Ruminants, pp. 665-684 [Y. Ruckebusch and P. Thivend, editors]. Lancaster: MTP Press.

Hörnicke, H., Ruoff, G., Vogt, B., Clauss, W. \& Ehrlein, H. J. (1984). Laboratory Animals 18, 169-172.

Hukuhara, T. \& Neya, T. (1968). Japanese Journal of Physiology 18, 551-562.

Hume, I. D. \& Warner, A. C. I. (1980). In Digestive Physiology and Metabolism in Ruminants, pp. 665-684 [Y. Ruckebusch and P. Thivend, editors]. Lancaster: MTP Press.

Kunstýr, I., Peters, K. \& Gartner, R. (1976). Laboratory Animal Science 26, 166-170.

Lloyd, L. E., Dale, D. G. \& Crampton, E. W. (1958). Journal of Animal Science 17, 684-692.

Murai, M., Manda, T. \& Horiguchi, M. (1982). Experimental Herbivora 7, Suppl., 35-40. 
Pickard, D. W. \& Stevens, C. E. (1972). American Journal of Physiology 222, 1161-1166.

Sakaguchi, E., Becker, G., Rechkemmer, G. \& Engelhardt, W. v. (1985). Zeitschrift für Tierphysiologie, Tierernährung und Futtermittelkunde 54, 276-285.

Sakaguchi, E., Heller, R., Becker, G. \& Engelhardt, W. v. (1986). Journal of Animal Physiology and Animal Nutrition 55, 44-50.

Sakaguchi, E., Itoh, J., Shinohara, H. \& Matsumoto, T. (1981). British Journal of Nutrition 46, 503-512.

Slade, L. M. \& Hintz, H. F. (1969). Journal of Animal Science 28, 842-843.

Snedecor, G. W. \& Cochran, W. G. (1967). Statistical Methods, 6th ed. Ames: Iowa State University Press.

Thacker, E. J. \& Brandt, C. S. (1955). Journal of Nutrition 55, 375-385.

Udén, P., Rounsaville, T. R., Wiggans, G. R. \& Van Soest, P. J. (1982). British Journal of Nutrition 48, 329-339.

Udén, P. \& Van Soest, P. J. (1982). British Journal of Nutrition 47, 267-272.

Van Soest, P. J. (1963). Journal of the Association of Official Analytical Chemists 46, 829-835.

Van Soest, P. J. (1982). Nutritional Ecology of the Ruminant. Corvallis: O\&B Books Inc.

Van Soest, P. J. \& Wine, R. H. (1967). Journal of the Association of Official Analytical Chemists 50, 50-55.

Varga, F. (1976). Digestion 14, 319-324.

Williams, C. H., David, D. J. \& Iismaa, O. (1962). Journal of Agricultural Science, Cambridge 59, 381-385.

Williams, V. J. \& Senior, W. (1982). Australian Journal of Biological Science 35, 373-379. 